\title{
PROCYCLICALITY AND BANK LENDING BEHAVIOR IN INDONESIA: THE CASE OF DUAL BANKING SYSTEM
}

\author{
Muhamed Zulkhibri ${ }^{1}$ \\ Muhammad Rizky Prima Sakti ${ }^{2}$
}

\begin{abstract}
It is widely suggested in the literature that procyclicality of bank lending behavior may lead to financial instability. This study examines bank-lending channel over the business cycle for Indonesian dual banking system by ascertaining to what extent Islamic banks have a role in the credit smoothing. In this context, we utilize Indonesian dual banking system unbalanced panel data for the period 2001-2015. By employing two-step dynamic GMM estimators, the study shows that the bank lending behaviour are procyclical. However, when we categorize the lending behaviour into conventional and Islamic banks, the cyclicality of bank lending affects only for conventional banks. As for the Islamic banks, the business cycle does not affect their financing decision. Specifically, large Islamic banks are more counter-cyclical in their financing behavior than small and medium size Islamic banks. Robustness tests using different measures of loans and model specifications confirm the results that Islamic bank is more stable and less procyclical in the case of Indonesia banking system.
\end{abstract}

Keywords: Procyclicality, Bank Lending, Dual Banking System, GMM, Indonesia JEL Classification: E59, E69, G29

Received : September 18, 2017

Revised : August 9, 2018

Accepted : August 21, 2018

1. Senior Research Economist, Islamic Research and Training Institute, Islamic Development Bank, Jeddah Saudi Arabia. Tel: +966-12-646-6533; Fax: +966-12506047132. Email: khibri1974@yahoo.com.

2. Researcher, Islamic Economic Forum for Indonesian Development (ISEFID), Indonesia. 


\section{INTRODUCTION}

Financial instability has direct consequences to the economy that will lead to economic crisis or even recession. Historically, since the collapse of Bretton Wood Agreement, more than 400 episodes of financial crises have been recorded (Laeven \& Valencia, 2013). In recent years, the global financial meltdown has received a great attention of both regulators and academicians. One of the lessons of the recent global financial crisis is the importance of procyclicality of the banking sector. The procyclicality of banking sector that is probably strengthen the amplitude of the business cycle, may influence the stability of financial system and economic growth (Ascarya, et al. 2016).

Indonesia has experienced two major financial crises, namely the 1997 Asian financial crisis and 2008 global financial crisis. The former crisis had made Indonesia trapped into the acute condition, while Indonesia has shown a more resilient performance in the latter crises. Nonetheless, some challenges remain such as the increase number of shocks faced by financial institutions. This probably expands immediately because of the interconnectedness of financial system and further exacerbated by procyclical behavior of financial institutions in the economy (Utari et al., 2011). The key in preserving financial stability is to manage both domestic and financial imbalances such as credit growth, asset prices, and risk-taking activities in the financial sector.

Research on procyclicality and financial stability has gained momentum and popularity among policy makers and academia in the aftermath of global financial crisis. However, the literature on this topic have mainly devoted to conventional banking literature. Only few attempts carried out to explore these important issues for Islamic financial institutions. Given the dearth of research in comparing these two types of institutions, the objective of this research is to investigate banklending activities over the business cycle for Indonesian dual banking system. The choice of Indonesia for this research is due to the facts that Indonesia has a vast potential to become a next hub of global Islamic finance with well-planned government programs and regulatory framework.

The rest of this paper is organized as follows. In Section 2, we provide a review of literature pertaining to procyclicality and lending behavior. In Section 3, we describe the data and methodology. In Section 4, we deal with empirical findings and analysis. Finally, the conclusion is presented in Section 5.

\section{RELATED LITERATURE}

\subsection{Overview of Indonesian Islamic Banking}

Indonesia has been assumed to have tremendous potential in Islamic banking and finance. The blossom of Islamic banking industry has been started in the early 1990s with the establishment of Bank Muamalat Indonesia (BMI) and is considered as the top 10 developed Islamic finance globally (IRTI-Thomson Reuters Report, 2015). The size of Indonesia's Islamic finance industry in 2015 reaching to Rp 617 trillion, which equivalent to 3\% of total financial industry assets. Since 2010, the growth rate of Indonesia's Islamic finance surpassed its conventional peers, accounted for $139 \%$ and $42 \%$ respectively (IRTI-Thomson Reuters Report, 2015). 
Under the purview of Indonesia's Financial Services Authority (called as Otoritas Jasa Keuangan), Indonesia's Islamic banking and finance are expected to continue its growth and to show improvements. Indonesia's banking sector is dominating with vast commercial banks. As of today, there are 85 conventional commercial banks and 12 Islamic commercial banks. Besides, the number of Islamic banking costumers has incredibly boosted to 13 million customers across 3,000 offices network in Indonesia (Bank of Indonesia, 2015). As shown in Figure 1 , the Islamic banking industry in Indonesia still have small share in the range of $5 \%$ relative to its conventional peers.

The growth of assets, financing, and the third party funds are relatively stable from 2014-2016. Figure 2 shows that those variables reach the peak in October 2016, when the government launched the tax amnesty program. Although Islamic banking remains sound supported by strong capital, however, structural problem remain unresolved such as higher financing pricing as compared to conventional banks. The cost of funds of Islamic banks is less competitive relative to its conventional counterpart. In addition, Islamic banks have to use the correct business model to minimize the costs and to comply with Shari'ah principles. All of which can hinder the growth potential of Indonesia's Islamic banking in the future.

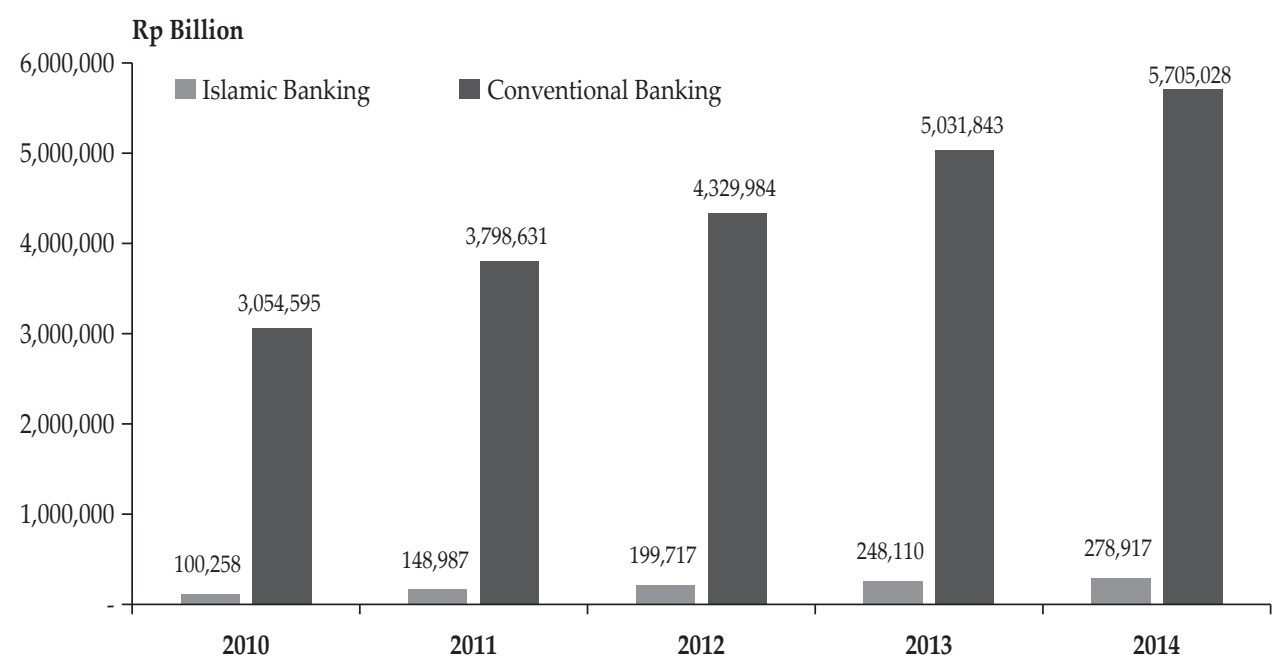

Source: Bank of Indonesia (2016)

Figure 1.

Comparison of Assets between Islamic and Conventional Banks in Indonesia 


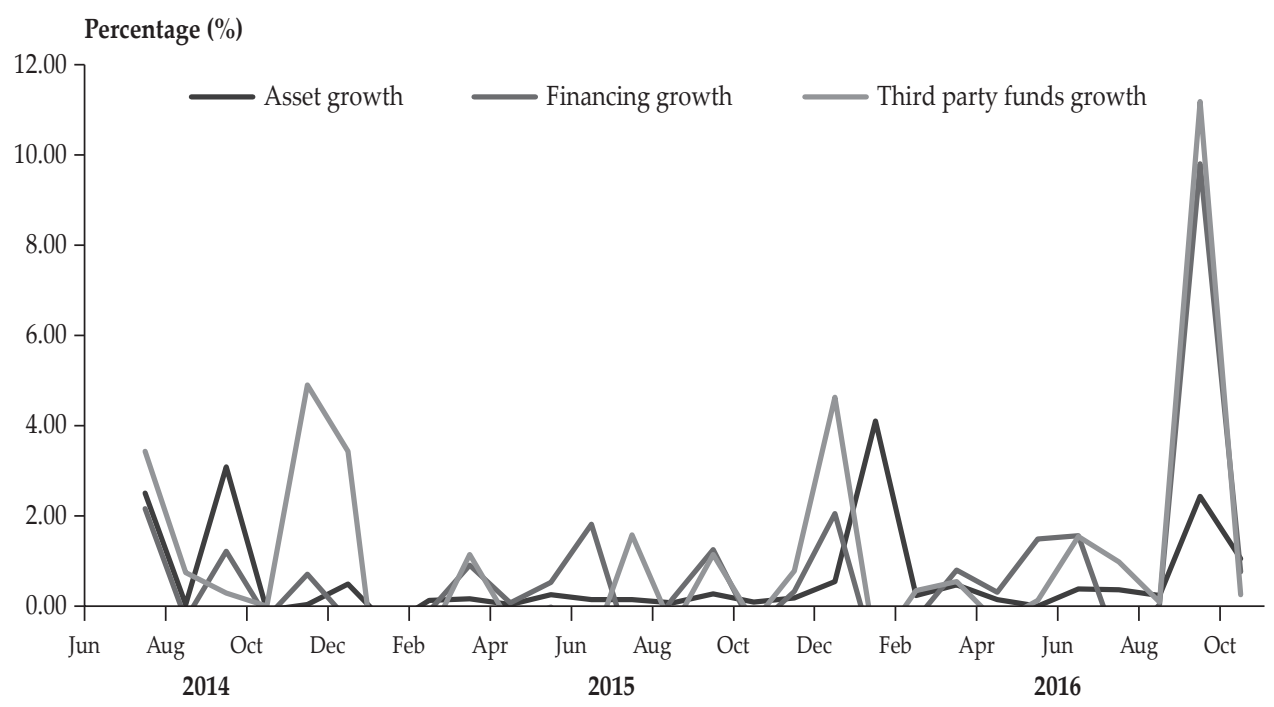

Source: Indonesia Financial Services Authority (2016)

Figure 2.

Islamic Banks Asset, Financing and Third Party Fund

\subsection{Related Studies on Procyclicality and Financial Stability}

Procyclicality of the banking system is being related to the under or overestimation of risks which amplify the cyclical behaviour between the banking institutions and the real economic sector. Many scholars consider that procyclicality of the banking sector as one of the main causes of financial instability in the economy. As suggested by Landau (2009), procyclicality of the banking sector may worsen business cycle fluctuations and leads to adverse effect to the financial stability. The interaction between the financial and real economic sector tend to reinforce the magnitude of business cycle. A simple description rarely copes with the behavior of financial system in real life as this system is characterized by feature of complexity. In most cases, the trajectory of asset prices will exhibit various and highly volatile.

Some studies raise the issues of risk and stability in Islamic banks and how they become more resilient than conventional banks (Čihák \& Hesse, 2010; Hasan \& Dridi, 2011). An analysis of behavior of Islamic banks becomes important due to several reasons; i) Islamic banks are closely interacted with conventional ones in dual-banking system, ii) Islamic banks have limited hedging instruments to protect their risk-exposure because of small asset size as compared to conventional one. Moreover, it is believed that Islamic bank is more stable and resilient to financial crisis and economic disturbances due to its inherent features. Farooq \& Zaheer (2015) argue that the resilience and stability of Islamic banks stem from their distinctive features; the ban of interest transactions, speculative transactions, and excessive risk-taking activities.

Many studies support that Islamic financial system is relatively stable due to its inherent features and moral values enshrined in the Shari'ah tenets (Buiter, 2014; 
Galati \& Moessner, 2013; Husman, 2015). These features involving the prohibition of interest in deposit-lending activities, the impermissible of leverage, and excessive speculation that trigger financial shocks in conventional peers (Buiter, 2014). In Islamic jurisprudence, interest is viewed as usurious and hence impermissible. The Shari'ah scholars approve for equity-based transactions according to the concepts of profit and loss sharing (PLS) and the trade-based (al-bay) transactions, in which it has a crucial impact to the stability of Islamic financial system.

Chapra (2009) argues that PLS contract ensures greater discipline by making Islamic bank more vigilant in lending activities, at the same time, the depositors more cautious with the health of Islamic banks. Ultimately, such discipline carries the greater stability and even greater efficiency in Islamic financial institutions. Not just that, Islamic finance promotes the concept of justice and fairness. As stipulated in Shari'ah law of contract, any parties that are engaged in business transaction have to share their own profits and risks to cope with the concepts of justice and fairness.

Given the facts about the salient features of Islamic financial system, one may conclude that Islamic financial system has intrinsic stability rather than conventional-based system. It has been shown that Islamic finance could be the solution to mitigate financial instability problems (Buiter, 2014). Stakeholders in financial sector are encouraged to adopt Islamic finance, while some suggest banking sector to convert excessive leverage into Islamic equity due to the relationship between procyclicality and financial stability (Ascarya et al., 2016; Husman, 2015; Ibrahim, 2016; Louati \& Boujelbene, 2015).

In contrary, a group of scholars have undermined the distinctive features of Islamic banks that make them immune and resilience to economic disruptions (Abdul-Rahman et al., 2014; Azmat et al., 2015; Chong \& Liu, 2009; Zulkhibri \& Sukmana, 2017). Chong \& Liu (2009) and Zulkhibri \& Sukmana (2017) argue that there is no substantial differences between Islamic and conventional banks in the case of Malaysia banking system because the profit-loss sharing (PLS) based assets highlighted as a peculiarity of Islamic banks constitute a low proportion of the overall Islamic banks' assets. Other scholars cast a doubt about the ability of Islamic banks to uplift the PLS-based assets in the current Islamic banking system, which are likely to be more influenced by adverse shocks (Abdul Rahman et al, 2014; Asmat et al, 2015)

Aside from that, the high concentration of Islamic banks assets and the limited hedging instruments due to restrictions by sharia principles, all of which contribute to instability of Islamic banking system in the face of adverse disruptions (Beck, Demirgüç-Kunt, \& Merrouche, 2013). Similarly, Hasan and Dridi (2011) reveal that the performance of Islamic banks is negatively influenced when the crisis hit the real sector. Cihak \& Hesse (2010) also support the view that large size Islamic bank is less stable as compared to large size conventional banks. Thus, all of which have pointed to skepticism towards the stability view, that is, Islamic banks are more stable and more resilience during the turbulence times.

Literature in Islamic finance also highlighted the importance separation between tools that address time series properties of financial stability (Ascarya et al., 2016), and cross-section dimension (Aysan et al., 2016; Ghosh, 2016). Ascarya et al. (2016) examine procyclicality of Indonesian banking sector by using a set of 
econometric techniques. The study shows that Islamic bank is more procyclical than conventional banks. Nonetheless, the procyclicality behavior of Islamic bank can be viewed as positive procyclicality. Accordingly, the Islamic banks procyclicality do not cause credit bubbles, thus it can bring benefits for economic growth in the long run. The literature has highlighted several instruments to address procyclicality such as loan-loss provisions (Lee et al., 2016; Zhang \& Zoli, 2016). A loan-loss provision ${ }^{3}$ is an important instrument through which the misassessment of risk can strengthen financial cycle (Galati \& Moessner, 2013).

Another line of research on financial stability examines the systemic risk problems of individual Islamic financial institution or Islamic financial system as a whole (Blundell-wignall \& Roulet, 2014; Ghosh, 2016) with respect to interconnectedness among financial institutions and the availability substitutes. Blundell-wignall \& Roulet (2014) argue systemic risks arise because financial institutions are actively deal with credit activities, maturity transformation, and leverage transactions. There is high complexity and interdependence in the financial system. The calibration of macro prudential policy seems relatively difficult than counter-cyclical rules.

\section{METHODOLOGY}

\subsection{Data}

Bank lending procyclicality indicators for Islamic and conventional banks are sourced from Bank Scope database from Bureau Van Dijk Company, while macroeconomic information is sourced from Bank of Indonesia website. The study includes 60 banks that consists of 50 conventional banks and 10 Islamic banks with dataset spans from 2001 to 2015 period.

\subsection{Methodology}

This study employs the system Generalized Method of Moments (GMM) estimator as proposed by Arellano \& Bover (1995) and Blundell \& Bond (1998). In essence, the dynamic GMM estimator is an instrumental variable estimator that uses lagged value of endogenous variables as well as lagged and current values of all strictly exogenous variables as their instruments. There are two types of estimators; onestep and two-step estimators. The former estimator, also known as first-differenced GMM, use the difference of each variable for both dependent and independent variables in the regressions and create instrument variables from the lagged levels of the independent variables. These lagged levels could be a weak instrument if there is a presence of serial correlation in the disturbance term.

The instrumental variables are essentially the lagged variables among the explanatory variables in the GMM estimation. It is unlikely that this lagged variable would be associated with the unobserved heterogeneity effect, thus the dynamic panel regression solves the presence of endogenousity problem. For this reason,

3. Banks have considerable policy of their loan-loss provisioning for bad loans. When comes to mounting losses, banks will hold back on the provisioning for bad debt to preserve their capital. 
this study opts for the dynamic panel regression, as it is more robust, unbiased and efficient estimator, and particularly in solving endogenousity problem in a panel data. Blundell \& Bond (1998) show that the system GMM has relatively small variances and more consistent and efficient, hence improving the precision in the estimator. The dynamic panel based on GMM addresses the problems of endogenousity, heteroscedasticity, and autocorrelation in the panel data.

In the GMM estimator, the assumption of there is no second order serial correlation in the first differences of error term is required; otherwise, the instruments become invalid. As for the model specification tests, the GMM estimator use the Sargan test of over-identifying restrictions and the test of lack of residual serial correlation. The Sargan test is based on the sample analogue of the moment conditions; it can use to determine the validity of predetermines assumption, endogenousity, and exogenousity.

Baltagi (2008) explains the existence of a lagged dependent variable is a unique characteristic of a dynamic panel model. The model in this study follows a oneway error component model and can be written as follows:

$$
\begin{aligned}
& Y_{i t}=\alpha Y_{i t-1}+\beta X_{i t}^{\prime}+\varepsilon_{i t} \\
& \varepsilon_{i t}=\mu_{i t}+v_{i t}
\end{aligned}
$$

where:

$Y_{i t} \quad=$ Level of deflated gross loan of bank $i$ in period $t$

$Y_{i t-1}=$ The lagged of deflated gross loan of bank $i$ in period $t$

$\alpha^{\prime}=$ A scalar

$X^{\prime}{ }_{i t} \quad=$ The explanatory variables of bank $i$ in period $t$

$\varepsilon_{i t} \quad=$ A random error term which consists of two components

$\mu_{i t} \quad=$ The unobservable time-invariant individual or bank specific effects

$v_{i t} \quad=$ The remainder disturbance

In this study, the empirical model is formulated to examine procyclicality of bank lending behavior and whether Islamic banks are less or more procyclical. We then specify the equation following Micco \& Panizza (2006) and Ibrahim (2016) as follows:

$$
\Delta L_{i t}=\gamma \Delta L_{i t-1}+\beta \Delta y_{t}+\theta X_{i t-1}+\pi i n f_{t}+\alpha_{i}+\varepsilon_{i t}
$$

where:

$L_{i t} \quad=$ Natural logarithm of CPI-deflated gross loans of bank $i$ in period $t$

$L_{i t-1} \quad=$ The lagged of CPI-deflated gross loans of bank $i$ in period $t$

$y^{\prime l-1} \quad=$ Natural logarithm of real GDP

$X_{i t-1} \quad=$ A vector of bank-specific variables

inf $_{t} \quad=$ Inflation

$\Delta \quad=$ The first difference of operator

$\alpha_{i} \quad=$ Bank-specific effects

$\varepsilon_{i t} \quad=$ A random error term 


\section{FINDING AND DISCUSSION}

\subsection{Descriptive Statistics}

Figure 3 exhibits the Indonesian macroeconomic performance, real GDP growth and inflation rate from 2001 to 2015. Indonesia experienced an average annual growth rate of 5.3 percent over the study period. Indonesia is relatively immune to global financial crisis in 2008/09 with growth rate during the financial crisis with average annual growth at 6 percent and 4 percent in 2008 and 2009 respectively. Lack exposure of toxic assets in financial sector and strong domestic demands in real sector, to name a few, are the important factors driving Indonesia economy into a positive real growth in global financial crisis. Indonesia inflation record has been relatively high of 7.6 percent per year over 2001 to 2015. It witnessed a swing trend from 2001 to 2009 before it relatively stable in 2010 onwards.

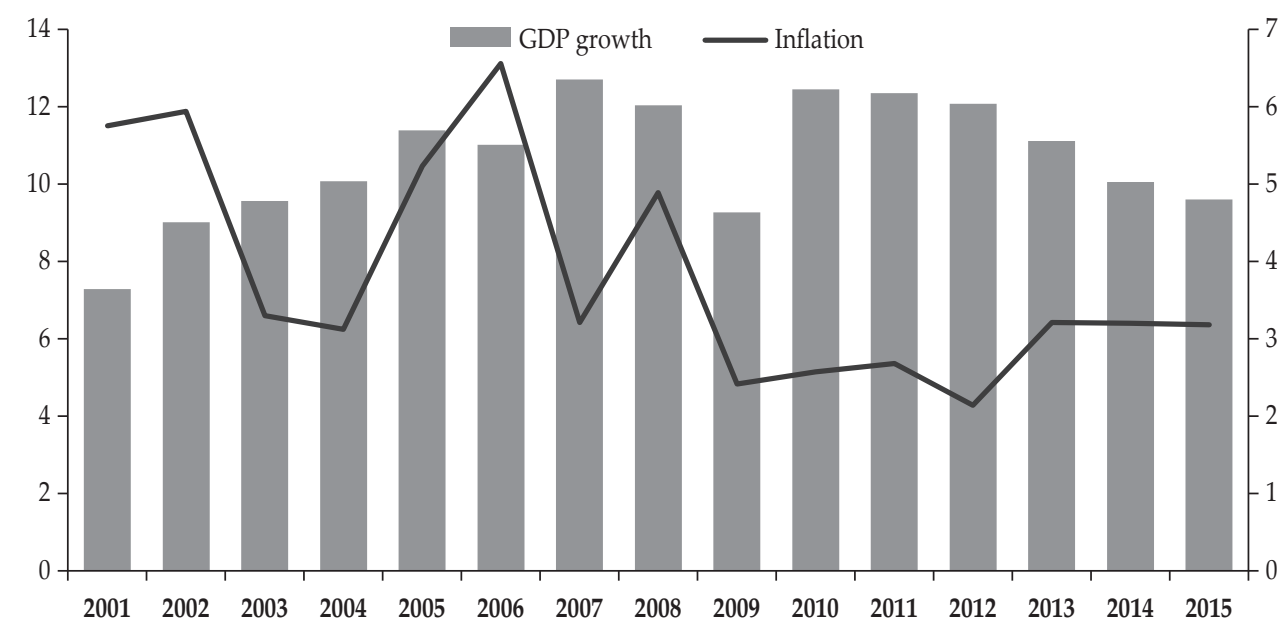

Source: Bank of Indonesia (2016)

Figure 3.

The Growth of Real GDP and Inflation over 2001-2015

Table 1 exhibits the descriptive statistics of bank loans and bank-specific characteristics, such as log real assets, equity to assets ratio, and loans to deposit ratio, for both Islamic and conventional banks. It is apparent that conventional banks are significantly larger than Islamic banks, as indicated by their greater size and loans, while the growth rate of conventional bank lending was at 32 percent over 2001-2015 periods. The growth for Islamic bank financing was relatively better over 40 percent over the same period. Islamic banks are better capitalized as indicated with higher equity to asset ratio of 17.4 percent as opposed 11 percent for conventional banks. The funding ratio as indicated by loans to deposit ratio, is relatively higher for Islamic banks. 
Table 1.

Descriptive Statistics

\begin{tabular}{|c|c|c|c|c|c|c|c|c|}
\hline \multirow{2}{*}{ Variables } & \multicolumn{4}{|c|}{ All samples } & & & & \\
\hline & Mean & Std. Dev & Min & $\operatorname{Max}$ & & & & \\
\hline Gross loans & $40,300,000$ & $77,100,000$ & 11,300 & $590,000,000$ & & & & \\
\hline \multicolumn{9}{|l|}{ (in Rupiah) } \\
\hline$\%$ growth & 32.77 & 54.71 & -83.53 & 666.79 & & & & \\
\hline Net loans & $38,800,000$ & $74,200,000$ & 7,600 & $570,000,000$ & & & & \\
\hline \multicolumn{9}{|l|}{ (in Rupiah) } \\
\hline$\%$ growth & 33.61 & 55.66 & -42.42 & 667.55 & & & & \\
\hline Real assets (log) & 16.9 & 1.63 & 12.61 & 20.63 & & & & \\
\hline Equity-asset ratio (\%) & 12.21 & 7.64 & -7.15 & 63.23 & & & & \\
\hline Loans-deposits ratio (\%) & 91.84 & 73.28 & 1.23 & 712.41 & & & & \\
\hline \multirow{2}{*}{ Variables } & \multicolumn{4}{|c|}{ Conventional Banks } & \multicolumn{4}{|c|}{ Islamic Banks } \\
\hline & Mean & Std. Dev & Mean & Std. Dev & Mean & Std. Dev & Mean & Std. Dev \\
\hline Gross loans & $44,900,000$ & $81,700,000$ & 11,300 & $590,000,000$ & $10,400,000$ & $13,700,000$ & 97,930 & $50,000,000$ \\
\hline \multicolumn{9}{|l|}{ (in Rupiah) } \\
\hline$\%$ growth & 31.59 & 56.76 & -83.53 & 666.79 & 41.06 & 36.4 & -23.61 & 140.91 \\
\hline Net loans & $43,200,000$ & $78,600,000$ & 7,600 & $570,000,000$ & $10,100,000$ & $13,200,000$ & 63,662 & $49,000,000$ \\
\hline \multicolumn{9}{|l|}{ (in Rupiah) } \\
\hline$\%$ growth & 32.52 & 57.71 & -42.42 & 667.55 & 41.3 & 37.66 & -31.25 & 147.62 \\
\hline Real assets (log) & 17.1 & 1.58 & 12.61 & 20.63 & 15.63 & 1.4 & 12.74 & 18.07 \\
\hline Equity-asset ratio (\%) & 11.41 & 5.28 & -7.15 & 51.07 & 17.42 & 15.1 & 5.48 & 63.23 \\
\hline Loans-deposits ratio (\%) & 81.57 & 37.19 & 1.23 & 326.42 & 164.23 & 166.85 & 66.75 & 712.41 \\
\hline
\end{tabular}

\subsection{System GMM - Baseline Results}

Table 2 below presents the results of the dynamic panel data estimation using the two-step system GMM analysis. In Model 3, we have the baseline regression model, which includes variables such as bank-specific variables and inflation rates. Model 1 and Model 3 incorporate only bank specific variables, while Model 2 and Model 4 include inflation rate as a proxy for controlled variables. The Sargan test fails to reject the over-identification restrictions, indicating that the validity of instruments. Moreover, the serial correlation test (autocorrelation test) does not reject the null of second-order autocorrelation. The residual of level equation (prior differencing) do not suffer from the autocorrelation problems. Both Sargan and autocorrelation tests affirm the model to be estimated using the GMM estimation approach. 
Table 2.

System GMM Estimation - Baseline Results

\begin{tabular}{|c|c|c|c|c|}
\hline Variables & -1 & -2 & -3 & -4 \\
\hline \multirow[t]{2}{*}{$\Delta \mathrm{L} 1_{\mathrm{it}-1}$} & $0.650^{* * *}$ & $0.683^{* * *}$ & $0.648^{* * *}$ & $0.677^{* * *}$ \\
\hline & $(0.000)$ & $(0.000)$ & $(0.000)$ & $(0.000)$ \\
\hline \multirow[t]{2}{*}{$\Delta y_{\text {it }}$} & $0.147^{* * *}$ & $0.131^{*}$ & $0.199^{* * *}$ & $0.553^{* *}$ \\
\hline & -0.09 & -0.079 & 0 & -0.028 \\
\hline \multirow{2}{*}{$\Delta y_{i t} \times I_{i}$} & - & - & $-0.331^{* * *}$ & $-0.629^{* * *}$ \\
\hline & & & $(0.000)$ & $(0.000)$ \\
\hline \multirow[t]{2}{*}{ LnSIZE $_{\mathrm{it}-1}$} & $0.302^{* * *}$ & $0.251^{* * *}$ & $0.315^{* * *}$ & $0.269^{* * *}$ \\
\hline & $(0.000)$ & $(0.000)$ & $(0.000)$ & 0 \\
\hline \multirow[t]{2}{*}{$\mathrm{CAP}_{\mathrm{it}-1}$} & $-0.027^{* * *}$ & $0.028^{* * *}$ & $-0.027^{* * *}$ & $-0.028^{* * *}$ \\
\hline & $(0.000)$ & $(0.000)$ & $(0.000)$ & $(0.000)$ \\
\hline \multirow[t]{2}{*}{ FUNDit-1 } & $0.0003^{* *}$ & $0.0002^{* *}$ & $0.0003^{* *}$ & $0.0002^{*}$ \\
\hline & $(0.034)$ & $(0.031)$ & $(0.039)$ & $(0.078)$ \\
\hline \multirow[t]{2}{*}{$\operatorname{Inf}_{t}$} & - & $-0.011^{* * *}$ & - & $-0.010^{* * *}$ \\
\hline & & $(0.000)$ & & $(0.000)$ \\
\hline \multicolumn{5}{|l|}{$P$ P-values } \\
\hline $\mathrm{AR}(2)$ & 0.1476 & 0.25 & 0.1565 & 0.2521 \\
\hline Sargan test & 0.2151 & 0.2461 & 0.217 & 0.2258 \\
\hline
\end{tabular}

Note: number in parentheses ( ) are p-values

$* * *, * * *$ indicates significance at $1 \%, 5 \%$, and $10 \%$ alpha respectively

Table 2 provides the result from Model 1 and Model 2 that bank size and capitalization ratio, and funding ratio are significant. We also find evidence that support procyclicality of bank lending in Indonesia, which is in line with Ibrahim (2016), and Ascarya et al. (2016). The findings from Model 1 and Model 2 indicate that a one percentage point increase in GDP growth is associated to approximately 0.13 to 0.14 percentage point increase in the growth of real loans. Moreover, we include Islamic bank interactive dummy in Model 3 and Model 4 to test the significance difference of conventional bank loans and Islamic bank financing. This can be explained by the significant estimated coefficient of the Islamic bank interactive dummy.

Table 2 indicates that Islamic bank financing increases more than two times than the conventional loans with respect to real GDP. A one-percentage point increase in real GDP increases 0.19 percentage point and 0.55 percentage point in real gross loans of conventional banks and Islamic banks respectively. The coefficient of Islamic bank interactive dummy in Model 3 and Model 4 are negative and significant at $1 \%$ level. This suggests that Islamic banks apparently are more counter-cyclical than conventional ones. The result is contrary to Ascarya et al. (2016) that find Islamic banks are more procyclical than conventional banks.

\subsection{System GMM Results - Based on Different Size Groups}

We also consider the size of the banks to explain bank lending procyclicality between Islamic and conventional banks. We use loan over total assets (lnSIZE) as a proxy to determine the classification of size groups. We disaggregate the sample 
into three subsamples according to size: large (above 75th percentile), medium (between 25th and 75th percentile) and small (below 25th percentile). Table 3 shows the different size of the banks with regard to bank lending procyclicality between Islamic and conventional banks. Similar with baseline results, the Sargan test fails to reject the over-identification restrictions. Moreover, the serial correlation test (autocorrelation test) does not reject the null of second-order autocorrelation.

Table 3.

System GMM Estimation Results (Based on different size groups)

\begin{tabular}{lccc}
\hline \multicolumn{1}{c}{ Variables } & $\begin{array}{c}\text { Model 1 } \\
\text { (small size) }\end{array}$ & $\begin{array}{c}\text { Model 2 } \\
\text { (medium size) }\end{array}$ & $\begin{array}{c}\text { Model 3 } \\
\text { (large size) }\end{array}$ \\
\hline$\Delta \mathrm{L}_{\mathrm{it}-1}$ & $0.269^{*}$ & $0.341^{* * * *}$ & $0.685^{* * *}$ \\
& $(0.074)$ & $(0.000)$ & $(0.000)$ \\
$\Delta \mathrm{y}_{\mathrm{it}}$ & $0.108^{* * *}$ & $0.660^{* * *}$ & $0.186^{* * *}$ \\
& $(0.002)$ & $(0.000)$ & $(0.000)$ \\
$\Delta \mathrm{y}_{\mathrm{it}} \times \mathrm{IB}_{\mathrm{i}}$ & -0.531 & -0.674 & $-0.217^{*}$ \\
& -0.461 & $(0.296)$ & $(0.076)$ \\
LnSIZE $_{\mathrm{it}-1}$ & $0.766^{* * *}$ & $0.609^{* * *}$ & $0.290^{* * *}$ \\
& $(0.000)$ & $(0.000)$ & $(0.000)$ \\
$\mathrm{CAP}_{\mathrm{it}-1}$ & $-0.015^{* * *}$ & $-0.002^{* * *}$ & $-0.027^{* * *}$ \\
& $(0.000)$ & -0.001 & $(0.000)$ \\
$\mathrm{FUND}_{\mathrm{it}-1}$ & $0.012^{* *}$ & $0.0002^{* *}$ & $0.005^{* *}$ \\
& -0.011 & $(0.034)$ & $(0.002)$ \\
Inf $_{\mathrm{t}}$ & $-0.0005^{*}$ & $-0.004^{* * *}$ & $-0.009^{* * *}$ \\
& $(0.087)$ & $(0.000)$ & $(0.000)$ \\
\hline P-values & & & \\
$\mathrm{AR}(2)$ & 0.4349 & 0.4126 & 0.7496 \\
Sargan test & 0.4528 & 0.4374 & 0.756 \\
\hline
\end{tabular}

Note: number in parentheses ( ) are p-values

$* * * * * * *$ indicates significance at $1 \%, 5 \%$, and $10 \%$ alpha respectively

Table 3 confirms that bank size, capitalization ratio and funding ratio are significant. We find evidences of bank lending procyclicality in Indonesia, which is in line with Bertray et al. (2015), Ibrahim (2016), and Ascarya et al. (2016). The findings indicate that a one percentage point increase in GDP is associated to approximately 0.11 to 0.66 percentage point increase real loans. The medium size group of Islamic banks has a greater Islamic financing than lower and large size groups, albeit it is not statistically significant. For medium size, a one-percentage point increase in real GDP increases 0.66 percentage point in Islamic financing group, while increases in Islamic financing for small and large size group of Islamic are only accounted for 0.10 and 0.18 percentage point respectively. This suggests that large Islamic bank tend to support the 'stability' view of Islamic banking system. 


\subsection{Robustness Check}

We then perform a set of robustness checks using net loan financing. Both of the Sargan and autocorrelation tests validate the instruments of GMM analysis. Table 4 indicates that Islamic banks tend to smooth their credit activities. The coefficient of Islamic bank interactive dummy in Model 3 and Model 4 are negative and significant which indicates the counter-cyclicality nature of Islamic bank financing. For control variables, all bank specific characteristics (size, capitalization and funding ratio) are significant. Inflation rate is negatively associated and significant, which support the baseline results of procyclicality nature of bank lending.

Table 4.

System GMM Estimation Results (Net loans)

\begin{tabular}{lcccc}
\hline \multicolumn{1}{c}{ Variables } & $-\mathbf{1}$ & $-\mathbf{2}$ & $-\mathbf{3}$ & -4 \\
\hline$\Delta \mathrm{L}_{\mathrm{it}-1}$ & $0.420^{* * *}$ & $0.448^{* * * *}$ & $0.457^{* * *}$ & $0.482^{* * *}$ \\
& $(0.000)$ & $(0.000)$ & $(0.000)$ & $(0.000)$ \\
$\Delta \mathrm{y}_{\mathrm{it}}$ & $0.431^{* * *}$ & $0.281^{* * *}$ & $0.393^{* * *}$ & $0.465^{* * *}$ \\
& $(0.000)$ & $(0.000)$ & $(0.000)$ & $(0.000)$ \\
$\Delta \mathrm{y}_{\mathrm{it}} \times \mathrm{IB}_{\mathrm{i}}$ & - & - & $-0.426^{* * *}$ & $-0.526^{* * *}$ \\
& & & $(0.000)$ & $(0.000)$ \\
$\mathrm{LnSIZE}_{\mathrm{it}-1}$ & $0.514^{* * *}$ & $0.467^{* * *}$ & $0.482^{* * *}$ & $0.438^{* * *}$ \\
& $(0.000)$ & $(0.000)$ & $(0.000)$ & $(0.000)$ \\
$\mathrm{CAP}_{\mathrm{it}-1}$ & $-0.019^{* * *}$ & $-0.021^{* * *}$ & $-0207^{* * *}$ & $-0.021^{* * *}$ \\
$\mathrm{FUND}_{\mathrm{it}-1}$ & $(0.000)$ & $(0.000)$ & $(0.000)$ & $(0.000)$ \\
& $0.0005^{* *}$ & $0.0005^{* *}$ & $0.0005^{* *}$ & $0.0005^{* * *}$ \\
Inf $_{\mathrm{t}}$ & $(0.000)$ & $(0.000)$ & $(0.000)$ & $(0.000)$ \\
& - & $-0.008^{* * *}$ & - & $-0.008^{* * *}$ \\
\hline P-values & & $(0.000)$ & & $(0.000)$ \\
$\mathrm{AR}(2)$ & & & & \\
Sargan test & 0.1456 & 0.2069 & 0.1665 & 0.1632 \\
\hline
\end{tabular}

Note: number in parentheses ( ) are p-values

***, **, ${ }^{*}$ indicates significance at $1 \%, 5 \%$, and $10 \%$ alpha respectively

We also perform the robustness check for the dynamic regressions based on different size of banks. Table 5 shows the GMM estimation results using net loan growth model. The results indicate that Islamic banks have a crucial role in smoothing the credit activities. Both diagnostic tests, Sargan and autocorrelation test indicates the adequacy of model using GMM procedure. Most of bank specific characteristics carry significant coefficients, except for funding ratio. Inflation rate is negative and statistically significant, except form small size group. However, the interaction terms for small and medium size Islamic bank and real GDP s not significant. This result confirms the 'stability' view of large size Islamic banks. 
Table 5.

System GMM Estimation Results (Net loans, based on different size groups)

\begin{tabular}{|c|c|c|c|}
\hline Variables & $\begin{array}{c}\text { Model 1 } \\
\text { (small size) }\end{array}$ & $\begin{array}{c}\text { Model 2 } \\
\text { (medium size) }\end{array}$ & $\begin{array}{c}\text { Model } 3 \\
\text { (large size) }\end{array}$ \\
\hline \multirow{2}{*}{$\Delta \mathrm{L}_{\mathrm{it}-1}$} & $0.268^{* * *}$ & $0.341^{* * *}$ & $0.476^{* * *}$ \\
\hline & -0.007 & 0 & 0 \\
\hline \multirow[t]{2}{*}{$\Delta y_{\text {it }}$} & $0.108^{* * *}$ & $0.661^{* * *}$ & $0.169^{*}$ \\
\hline & -0.002 & 0 & -0.091 \\
\hline \multirow{2}{*}{$\Delta y_{i t} \times I_{i}$} & -0.153 & -0.694 & $-0.210^{*}$ \\
\hline & -0.461 & -0.296 & -0.061 \\
\hline \multirow[t]{2}{*}{$\operatorname{LnSIZE}_{\mathrm{it}-1}$} & $0.766^{* * *}$ & $0.609^{* * *}$ & $0.394^{* * *}$ \\
\hline & 0 & 0 & 0 \\
\hline \multirow{2}{*}{$\mathrm{CAP}_{\mathrm{it}-1}$} & $-0.015^{* * *}$ & $0.002^{* *}$ & $-0.011^{* * *}$ \\
\hline & 0 & -0.001 & 0 \\
\hline \multirow[t]{2}{*}{ FUND $_{i t-1}$} & 0.001 & -0.0002 & $0.0002^{* *}$ \\
\hline & -0.119 & -0.314 & -0.003 \\
\hline \multirow[t]{2}{*}{$\operatorname{Inf}_{t}$} & 0.0005 & $-0.004^{* * *}$ & $-0.011^{* * *}$ \\
\hline & -0.874 & 0 & 0 \\
\hline \multicolumn{4}{|l|}{ P-values } \\
\hline $\mathrm{AR}(2)$ & 0.4349 & 0.4126 & 0.231 \\
\hline Sargan test & 0.4629 & 0.8153 & 0.278 \\
\hline
\end{tabular}

Note: number in parentheses ( ) are p-values

$* * * * * *$ indicates significance at $1 \%, 5 \%$, and $10 \%$ alpha respectively

\section{CONCLUSIONS}

We examine bank-lending behavior over the business cycle in a dual banking system in Indonesia By using dynamic system GMM approaches and bank-level panel data set of 60 banks over the period of 2001 to 2015, the results suggest procyclicality of bank lending for both Islamic and conventional banks in Indonesia. However, when we categorize into conventional loans and Islamic financing, the evidence shows that conventional bank is procyclical, while we find no support that Islamic bank is procyclical in their financing behaviour.

The study also suggests the role played by Islamic banks in smoothing their financing behavior during the time of economic downturns as evidence in the Islamic bank and large bank interactive dummy. In all cases, the evidences support that Islamic banks are counter-cyclical than conventional banks in line with Farooq and Zaheer (2015) and Ibrahim (2016). Islamic banks in Indonesia have been able to stabilize their financing during the recent economic recessions. It is not surprising that Indonesian Islamic banks performed well during the global financial crisis albeit the crisis hit hard the global economy.

Procyclicality of financing behavior as one the major causes of systemic risk are well understood by the regulators. However, the indications that Islamic banks in Indonesia behaving counter-cyclical, while conventional banks behaving procyclical in their lending activities require different policy formulation. It is suggested that designing a sound framework and effective instruments is important to address the differential nature of lending behaviour between these 
two banking system. A unique macro prudential policies and framework for Islamic and conventional banks is essential in order to prevent systemic risk and financial imbalances.

\section{REFERENCES}

Abdul-Rahman, A., Abdul Latif, R., Muda, R., \& Abdullah, M. A. (2014). Failure and potential of profit-loss sharing contracts: A perspective of New Institutional, Economic (NIE) Theory. Pacific Basin Finance Journal, 28, 136-151. http://doi. org/10.1016/j.pacfin.2014.01.004

Arellano, M., \& Bover, O. (1995). Another look at the instrumental variable estimation of error-components models. Journal of Econometrics, 68(1), 29-51.

https://doi.org/10.1016/0304-4076(94)01642-D

Ascarya, Rahmawati, S., \& Karim, A. A. (2016). Testing the procyclicality of Islamic and conventional banks in Indonesia. In: Zulkhibri, M., Ismail, A., \& Hidayat, S. (eds). Macroprudential Regulation and Policy for the Islamic Financial Industry. Cham: Springer.

https://doi.org/10.1007/978-3-319-30445-8_8

Aysan, A., Disli, M., \& Ozturk, H. (2016). Financial crisis, macroprudential policies and depositor discipline. The Singapore Economic Review, 62(1), 5-25. http://doi. org/10.1142/S021759081740001X

Azmat, S., Skully, M., \& Brown, K. (2015). Can Islamic banking ever become Islamic? Pacific-Basin Finance Journal, 34, 253-272 http://doi.org/10.1016/j. pacfin.2015.03.001

Bank Indonesia (2015). Monthly Statistics Report, Indonesian Islamic Banking. Jakarta: Bank Indonesia.

Beck, T., Demirgüç-Kunt, A., \& Merrouche, O. (2013). Islamic vs. conventional banking: Business model, efficiency and stability. Journal of Banking $\mathcal{E}$ Finance, 37(2), 433-447. http://doi.org/10.1016/j.jbankfin.2012.09.016

Blundell-wignall, A., \& Roulet, C. (2014). Macro-prudential policy, capital controls and bank systemic risk. In: Shigehara, K. (eds). The Limits of Surveillance and Financial Market Failure. London: Palgrave Macmillan.

https://doi.org/10.1057/9781137471475_9

Blundell, R., \& Bond, S. (1998). Initial conditions and moment restrictions in dynamic panel data models. Journal of Econometrics, 87(1), 115-143.

https://doi.org/10.1016/S0304-4076(98)00009-8

Buiter, W. H. (2014). The role of central banks in financial stability : How has it changed? World Scientific, 30, 11-56.

https://doi.org/10.1142/8720

Chapra, M. U. (2009). The Global Financial Crisis: Some suggestion from Islamic Finance. Kyoto.

Chong, B. S., \& Liu, M.-H. (2009). Islamic banking: Interest-free or interestbased? Pacific-Basin Finance Journal, 17(1), 125-144. http://doi.org/10.1016/j. pacfin.2007.12.003

Čihák, M., \& Hesse, H. (2010). Islamic banks and financial stability: An empirical analysis. Journal of Financial Services Research, 38(2-3), 95-113.

http://doi.org/10.1007/s10693-010-0089-0 
Farooq, M., \& Zaheer, S. (2015). Are Islamic banks more resilient during financial panics? Pacific Economic Review, 20(1), 101-124. http://doi.org/10.1111/14680106.12096

Galati, G., \& Moessner, R. (2013). Macroprudential policy - a literature review. Journal of Economic Surveys, 27(5), 846-878. http://doi.org/10.1111/j.14676419.2012.00729.x

Ghosh, S. (2016). Macroprudential policies, crisis and risk-taking: Evidence from dual banking systems in GCC countries. Journal of Islamic Accounting and Business Research, 7(1), 6-27.http://doi.org/http://dx.doi.org/10.1108/09564230910978511

Hasan, M., \& Dridi, J. (2011). The effects of the global crisis on Islamic and conventional banks: A comparative study. Journal of International Commerce, Economics and Policy, 2(2), 163-200. http://doi.org/10.1142/S1793993311000270

Husman, J. (2015). Essays on Banking and Monetary Policy in the Presence of Islamic Banks. University of Warwick.

Ibrahim, M. H. (2016). Business cycle and bank lending procyclicality in a dual banking system. Economic Modelling, 55, 127-134. http://doi.org/10.1016/j. econmod.2016.01.013

IRTI-Thomson Reuters (2015). Indonesia Islamic Finance Report: Prospects For Exponential Growth. Jeddah: Islamic Research and Training Institute.

Laeven, L., \& Valencia, F. (2013). Systemic banking crises database. IMF Economic Review, 61(2), 225-270.

https://doi.org/10.1057/imfer.2013.12

Landau, J. (2009). Complexity and the financial crisis. Paper presented at the Conference on The Macroeconomy and Financial Systems In Normal Times and In Times of Stress, Bank of France and the Deutsche Bundesbank, Gouvieux-Chantilly.

Lee, M., Asuncion, R. C., \& Kim, J. (2016). Effectiveness of macroprudential policies in developing asia: An empirical analysis. Emerging Markets Finance and Trade, 52(4), 923-937. http://doi.org/10.1080/1540496X.2015.1103137

Louati, S., \& Boujelbene, Y. (2015). Banks' stability-efficiency within dual banking system: A stochastic frontier analysis. International Journal of Islamic and Middle Eastern Finance and Management, 8(4), 472-490.

https://doi.org/10.1108/IMEFM-12-2014-0121

Zhang, L., \& Zoli, E. (2016). Leaning against the wind: Macroprudential policy in Asia. Journal of Asian Economics, 42, 33-52. http://doi.org/10.1016/j. asieco.2015.11.001

Zulkhibri, M., \& Sukmana, R. (2017). Financing channels and monetary policy in a dual banking system: evidence from Islamic banks in Indonesia. Economic Notes, 46(1), 117-14. https://doi.org/10.1111/ecno.12076 
This page is intentionally left blank 